\title{
Observations of ozone depletion events in a Finnish boreal forest
}

\author{
Xuemeng Chen ${ }^{1}$, Lauriane L. J. Quéléver ${ }^{1}$, Pak L. Fung ${ }^{1}$, Jutta Kesti ${ }^{2}$, Matti P. Rissanen ${ }^{1}$, Jaana Bäck ${ }^{1}$, \\ Petri Keronen $^{1}$, Heikki Junninen ${ }^{1,3}$, Tuukka Petäjä ${ }^{1}$, Veli-Matti Kerminen ${ }^{1}$, and Markku Kulmala ${ }^{1}$ \\ ${ }^{1}$ Division of Atmospheric Sciences, Department of Physics, 00014 University of Helsinki, Finland \\ ${ }^{2}$ Atmospheric Composition Research, Finnish Meteorological Institute, P.O. Box 503, 00101 Helsinki, Finland \\ ${ }^{3}$ Institute of Physics, University of Tartu, Ülikooli 18, 50090 Tartu, Estonia
}

Correspondence: Xuemeng Chen (xuemeng.chen@helsinki.fi)

Received: 3 May 2017 - Discussion started: 22 June 2017

Revised: 13 October 2017 - Accepted: 7 November 2017 - Published: 3 January 2018

\begin{abstract}
We investigated the concentrations and vertical profiles of ozone over a 20-year period (1996-2016) at the SMEAR II station in southern Finland. Our results showed that the typical daily median ozone concentrations were in the range of $20-50 \mathrm{ppb}$ with clear diurnal and annual patterns. In general, the profile of ozone concentrations illustrated an increase as a function of heights. The main aim of our study was to address the frequency and strength of ozone depletion events at this boreal forest site. We observed more than a thousand of $10 \mathrm{~min}$ periods at $4.2 \mathrm{~m}$, with ozone concentrations below $10 \mathrm{ppb}$, and a few tens of cases with ozone concentrations below $2 \mathrm{ppb}$. Among these observations, a number of ozone depletion events that lasted for more than $3 \mathrm{~h}$ were identified, and they occurred mainly in autumn and winter months. The low ozone concentrations were likely related to the formation of a low mixing layer under the conditions of low temperatures, low wind speeds, high relative humidities and limited intensity of solar radiation.
\end{abstract}

\section{Introduction}

Ozone $\left(\mathrm{O}_{3}\right)$ is one of the most important compounds in atmospheric chemistry (e.g. Monks, 2005; Monks et al., 2015). It is a strong greenhouse gas and a key contributor to the oxidation capacity of the atmosphere (Toumi et al., 1994; Simpson et al., 2007). Ozone is also the principal source of the essential atmospheric oxidants, being the major photochemical precursor of the $\mathrm{OH}$ radical (Atkinson and Arey, 2003) and a source of the nocturnal $\mathrm{NO}_{3}$ radical through the $\mathrm{NO}_{2}+\mathrm{O}_{3} \rightarrow \mathrm{NO}_{3}$ reaction (Brown and Stutz, 2012). Very recently, the importance of ozone in initiating the au- toxidation of volatile organic compounds (VOCs) in the gas phase was recognized, producing rapidly a range of highly-oxidized multifunctional compounds (HOMs, Ehn et al., 2014; Rissanen et al., 2014), which can participate in the formation of secondary organic aerosols and/or contribute significantly on their early growth (Kulmala et al., 1998; Ehn et al., 2014; Trostl et al., 2016). While stratospheric ozone acts to shield the Earth from detrimental ultraviolet radiation, the tropospheric ozone is harmful for human health (e.g. Shang et al., 2013; Turner et al., 2016). It causes negative consequences throughout the biosphere (Gregg et al., 2003; Ashmore, 2005) and reduces crop yields (Emberson et al., 2001; Feng and Kobayashi, 2009), when it is either deposited to the surface of or taken up and then metabolized by plants.

The concentration of tropospheric ozone is governed by its sources and sinks. In the troposphere, $\mathrm{O}_{3}$ is produced via complex photochemical cycles involving VOCs and nitrogen oxides $\left(\mathrm{NO}_{x}\right.$ consists of $\mathrm{NO}$ and $\left.\mathrm{NO}_{2}\right)$ (Sillman et al., 1990; Sillman, 1999). Transport from the stratosphere brings additional ozone to its tropospheric budget. The tropospheric ozone is reduced directly by dry deposition, photolysis and reactions with other trace gases and indirectly via wet deposition of ozone precursors. The dry deposition of ozone can be enhanced under moist conditions (Fuentes et al., 1992). These contributions form an equilibrium state that maintains tropospheric ozone-mixing ratios at concentration levels of about tens of parts per billion (ppb) (Vingarzan, 2004; Monks et al., 2015). Although tropospheric ozone is relatively well mixed in a broad sense, its concentration can vary notably with both time and space depending on the prevailing meteorological conditions. Regional and local surface $\mathrm{O}_{3}$ con- 
centrations are affected, for example, by horizontal and vertical advections of pollutants, entrainment from the free troposphere and other boundary layer dynamic processes (Simpson et al., 2007; Cao et al., 2016; Tang et al., 2017; Wang et al., 2017; Zhou et al., 2017).

The most well-known ozone depletion phenomena are the stratospheric "ozone-hole" episodes taking place above the polar regions caused by the catalytic halogen chemistry (Molina and Rowland, 1974; Solomon, 1999), as well as the frequently reported $\mathrm{O}_{3}$ depletion events in a polar planetary boundary layer (Simpson et al., 2007). In addition, significant decreases in local surface $\mathrm{O}_{3}$ concentrations have been observed in polluted urban environments (Gregg et al., 2003). While in the polar areas halogenated compounds are responsible for most of the surface ozone destruction, in urban locations low local ozone concentrations are typically related to complex atmospheric chemistry involving anthropogenic pollutants, mainly nitrogen oxides (Gregg et al., 2003; US National Research Council, 1992). Also, low surface ozone concentrations were reported at different sites in the Amazonian forest (Rummel et al., 2007; Pacifico et al., 2015). Although anormal reductions in surface ozone concentrations have been observed at different geographical locations, there lacks a general characterization of the vertical features of such $\mathrm{O}_{3}$ depletion phenomena. Thus, it is imperative to study the vertical profile of $\mathrm{O}_{3}$ to provide insights into observations of surface ozone depletion.

Based on previously reported depletion events in surface ozone, we investigated in detail ozone concentrations and profiles using long-term ( $>20$ years) data collected between 1 January 1996 and 30 June 2016 at the Hyytiälä SMEAR II station, a boreal forest site in Finland. Our main goals in this study were (1) to characterize the typical seasonal and diurnal behaviour of vertical ozone concentration profiles within and above the boreal forest, (2) to evaluate statistically the low ozone concentration episodes, (3) to assess the atmospheric conditions in association with these lowconcentration episodes, and (4) to identify key atmospheric features during the ozone depletion events.

\section{Experimental setup and data analysis}

The SMEAR II (Station for Measuring forest EcosystemAtmosphere Relation) infrastructure, located in a boreal forest at Hyytiälä, southern Finland $\left(61^{\circ} 51^{\prime} \mathrm{N}, 24^{\circ} 17^{\prime} \mathrm{E}\right.$, $181 \mathrm{~m}$ a.s.l.), offers a unique set of information based on continuous measurements of atmospheric composition and meteorological variables (Hari and Kulmala, 2005). These measurements are located at several heights on a mast, ranging from below-canopy levels $(4.2,8.4$, and $16.8 \mathrm{~m})$ to abovecanopy levels (33.6, 50.4, 67.2, 101, and $125 \mathrm{~m}$ ), capturing the vertical profile of the lower atmosphere at this site. Snow on the ground during winter months is common at our measurement site, and the site can receive transported pollutants from nearby cities (e.g. Tampere and Helsinki) and continental areas (Riuttanen et al., 2013).

The forest stand is dominated by Scots pines (Pinus sylvestris L.) with an average height of $16-18 \mathrm{~m}$ (living canopy height ca. $10-12 \mathrm{~m}$ ) and age of 55 years. Other, less abundant species include Norway spruce (Picea abies L. H. Karst.), silver birch (Betula pendula Ehrh.) and trembling aspen (Populus tremula), which together form ca. $25 \%$ of the biomass (Ilvesniemi et al., 2009). The ground vegetation consists of dwarf shrubs (e.g. Vaccinium sp., Calluna vulgaris) and mosses (Pleurozium schreberi, Dicranum sp.). For most of the vertical measurement levels, the data were available since January 1996. But the highest measurement levels (101 and $125 \mathrm{~m}$ ) were introduced in February 2013. These data altogether form a continuous dataset of atmospheric observations over a 20 -year period.

\subsection{Trace gas measurements}

All the trace gas concentrations were recorded in every minute at all the aforementioned measurement levels. $\mathrm{O}_{3}$ concentrations were determined by a photometric TEI 49C ozone monitor (Thermo Fisher Scientific, Waltham, MA, USA). The instrument had a detection limit of $1 \mathrm{ppb}$ and a relative accuracy of $\pm 3 \%$.

Carbon monoxide $(\mathrm{CO})$ and carbon dioxide $\left(\mathrm{CO}_{2}\right)$ concentrations were quantified by their infrared (IR) absorption characteristics. CO was measured with a Horiba APMA 360 monitor (Horiba, Kyoto, Japan) with a detection limit of $20 \mathrm{ppb}$ and relative accuracy of $\pm 3 \% . \mathrm{CO}_{2}$ was measured with an URAS $4 \mathrm{CO}_{2}$ monitor (Mannesmann Hartmann \& Braun, Frankfurt am Main, Germany) that had a relative accuracy of $\pm 1 \%$ The $\mathrm{CO}_{2}$ signal was corrected for $\mathrm{H}_{2} \mathrm{O}$ vapour interference.

Nitrogen oxide $\left(\mathrm{NO}_{x}\right.$ consists of $\mathrm{NO}$ and $\left.\mathrm{NO}_{2}\right)$ concentrations were measured with a TEI 42CTL photometric analyser (Thermo Fisher Scientific, Waltham, MA, USA). The measurement had a $0.1 \mathrm{ppb}$ limit of detection during 2006 measurements and this was increased to $0.15 \mathrm{ppb}$ for the measurements conducted in 2009 due to modification of the instrument. The relative accuracy in all of the $\mathrm{NO}_{x}$ measurements was $\pm 10 \%$.

\subsection{Ancillary measurements}

The temperature was monitored from all the heights, up to $67.2 \mathrm{~m}$, with custom-made 4-wired PT-100 sensors. The measurement spots were shielded in order to avoid interferences due to solar radiation and ventilated by fans to ensure a homogeneity in the measured air parcel. The accuracy of the temperature measurement was estimated to $\pm 0.2^{\circ} \mathrm{C}$ via a comparison with a mercury-based thermometer.

From April 1998 to mid-June 2012, the relative humidity $(\mathrm{RH})$ values were obtained via measurement of dew point temperature and air temperature at $16.4 \mathrm{~m}$ on the sampling 
tower using a chilled mirror hygrometer (DewTrak Model 200M Meteorological Humidity System, EdgeTech, Marlborough, MA, USA). The measurement of the dew point and ambient temperatures were retrieved with an accuracy of $\pm 0.3^{\circ} \mathrm{C}$ given a RH accuracy of $\pm 3 \%$. Since 16 June 2012 , the relative humidity is directly measured with an $\mathrm{RH}$ sensor (Rotronic MP102H with Hygroclip HC2-S3, Rotronic AG, Bassersdorf, Switzerland), providing accuracy of $\pm 0.8 \%$.

The total global radiation was calculated as the sum of direct and diffuse solar radiations. The measurement was placed on a separate tower next to the mast at the height of $18 \mathrm{~m}$. The radiation was measured using pyranometers: a Reemann TP 3 pyranometer (Astrodata, Tõravere, Tartumaa, Estonia) from January 1996 to mid-June 2008, and a Middleton Solar SK08 First Class Pyranometer (Middleton Solar, Yarraville, Australia) since 15 June 2008. These devices have a detection limit of $5 \mathrm{~W} \mathrm{~m}^{-2}$. The irradiance of solar radiation on a hemispherical surface (sun disc) was monitored in a wavelength range of $0.30-4.8 \mu \mathrm{m}$, with an accuracy of $\pm 5 \%$.

Wind speeds at different levels of the mast were measured either with cup anemometers or ultrasonic anemometers, or both, with an accuracy of $\pm 0.1 \mathrm{~m} \mathrm{~s}^{-1}$. Cup anemometers (A101M/L, Vector Instruments, Rhyl, Clwyd, UK) were used for monitoring wind properties at 4.2, 8.4, 16.8, 33.6, 50.4, and $74 \mathrm{~m}$ from January 1996 to 4 September 2003. Thereafter, the cup anemometers were replaced at all the measurement levels by ultrasonic anemometers (Ultrasonic anemometer 2-D, Adolf Thies GmbH, Göttingen, Germany). Since 7 July 2011, the wind measurement level at $74 \mathrm{~m}$ has been moved down to $67.4 \mathrm{~m}$. Two 3-D ultrasonic anemometers (Metek uSonic-3, Elmshorn, Germany) were installed at 67.4 and $125 \mathrm{~m}$ in November 2015.

Friction velocity data were used to characterize the turbulent conditions. The friction velocity $\left(u_{*}\right)$ was determined as $30 \mathrm{~min}$ averages of square root of the covariance between horizontal and vertical winds (Monteith and Unsworth, 2013),

$u_{*}=\sqrt{\overline{u^{\prime} w^{\prime}}}$,

where $u^{\prime}$ and $w^{\prime}$ are the fluctuations in the horizontal and vertical winds, respectively. Horizontal and vertical winds were measured at $23.3 \mathrm{~m}$ with a fast-response acoustic anemometer (Solent HS1199) on the radiation tower.

For assessing the stability of the atmosphere, the potential temperatures were calculated using the following expression (e.g. Monteith and Unsworth, 2013):

$\theta=T\left(\frac{P_{0}}{P}\right)^{R / c_{\mathrm{p}}}$

where $T$ is the ambient temperature (in kelvin), $P_{0}$ is 1000 mbar, $P$ is the ambient pressure (in mbar), $R$ is the gas constant, and $c_{\mathrm{p}}$ is the isobaric heat capacity. For air, the ratio gas constant to isobaric heat capacity $\left(R / c_{\mathrm{p}}\right)$ typically has a value of 0.286 .

\subsection{Data processing and handling}

With the exception of wind data, both gas and meteorological data were arithmetically averaged into a 10 min time resolution. The wind data were treated as vectors, where the arithmetic averaging was applied to the two horizontal wind components of the decomposed vectors and the $10 \mathrm{~min}$ wind data were restored from these averaged components.

The duration of consecutive low ozone concentrations was determined based on the $10 \mathrm{~min}$ data for the concentrations below threshold values of 10, 5, 2, and $1 \mathrm{ppb}$. Occasionally, the data were available only for every second $10 \mathrm{~min}$ interval, mainly between January 1996 and February 1997 for all the heights and at heights of 101 and $125 \mathrm{~m}$ from February 2013 onwards. A gap-filling procedure was applied to such data in order to estimate the duration of a low-ozone episode: if ozone concentrations were found below a threshold in every second 10 min interval with the value in between being missing, then the missing value in between two low-concentration records was treated as a low-concentration point. Hereafter, the low-ozone episodes are referred to as ozone concentration drops, and when the ozone concentration remains below a given threshold $(10,5,2$, or $1 \mathrm{ppb})$ for more than $30 \mathrm{~min}$, it is considered an ozone depletion event. No screening according to snow on the ground was taken into account in our data analysis.

\section{Results and discussions}

\subsection{Diurnal and seasonal variations in ozone profiles}

A clear seasonality was seen in ozone concentrations at different heights (Fig. 1). The ozone concentrations were the highest in spring (March-April) at all heights and then declined towards the lowest values seen in early winter (November). This observation is similar to the reported feature in surface ozone concentrations at several northern midlatitude sites (Oltmans et al., 2006; Parrish et al., 2013). Atlas et al. (2003) and Vingarzan (2004) pointed out that the spring peak is probably caused by spring recovery of photochemical production (Dibb et al., 2003) and by ozone accumulation through winter (Liu et al., 1987) at the northern mid- to high latitudes, but hardly by transportation from the stratosphere, even though the intrusion of ozone from the stratosphere has been reported to be a major source of springtime ozone appearing in the middle troposphere at high northern latitudes (Dibb et al., 2003). Notably, starting from early summer and continuing until late autumn, ozone concentrations tended to increase with an increasing measurement height, being clearly the lowest close to the surface (Fig. 1). This feature is probably linked to some combination of the biotic ozone uptake by vegetation, ozone deposition on surfaces inside the forest and ozone loss through chemical reactions with forest 


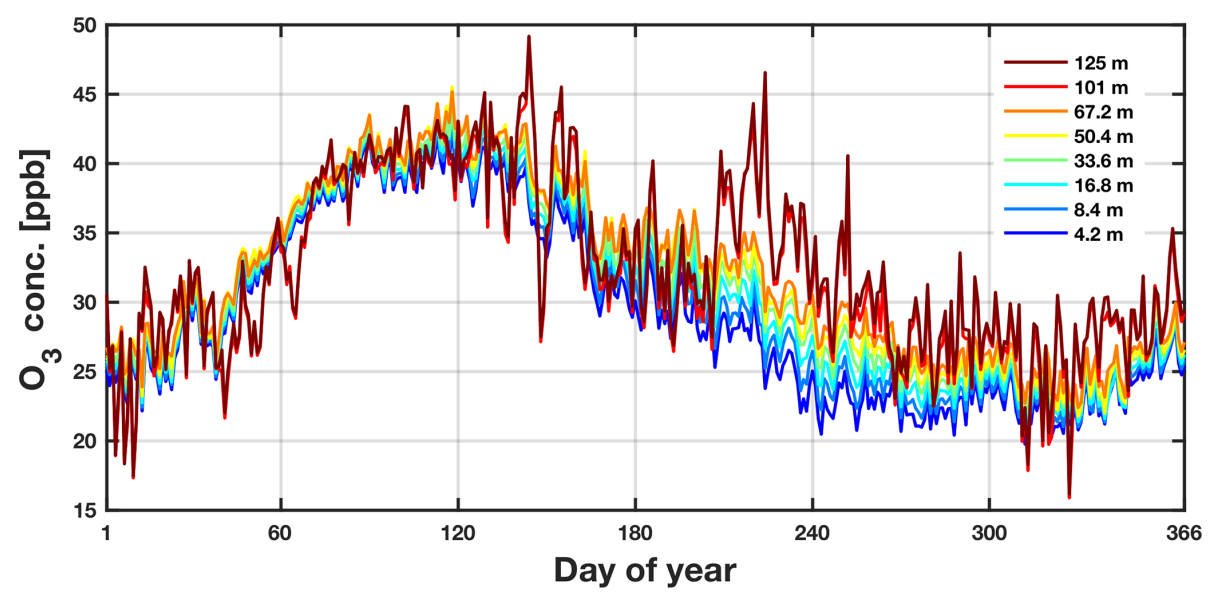

Figure 1. Daily medians of ozone concentrations at different heights for years 1996-2016. Heights are indicated by different colours.

emissions (Rannik et al., 2012; Monks et al., 2015; Clifton et al., 2017).

The diurnal behaviour of the vertical ozone concentration profile was similar in spring (March-May) and summer (June-August) (Fig. 2): a high ozone concentration was seen throughout the vertical extent of the measurements between about 10:00 and 20:00, likely related to the photochemical production of ozone. The highest ozone concentrations were generally seen above the canopy level (at about 50-60 m) during the daytime, with a clear decline with the decreasing height. This observation can be attributed to the loss of ozone by the forest (Rannik et al., 2012; Monks et al., 2015). During the evening in spring and summer, low ozone concentrations were first (at around 20:00) seen close to the ground and then later on gradually at levels higher up, so that the diurnal minimum ozone concentration was reached between about 05:00 $(4.2 \mathrm{~m})$ and 08:00 $(125 \mathrm{~m})$. This phenomenon results from the ozone deposition at night, when the photochemical production of ozone is prohibited. Ozone can also be consumed through oxidation reactions with biogenic organic compounds that are accumulated in the nocturnal boundary layer (Hakola et al., 2012). After sunrise, turbulent mixing in the boundary layer is initiated, leading to an increase in the mixed layer height and entrainment of ozone into this layer from above, in addition to which ozone starts to form via photochemical reactions. As a consequence, the ozone concentrations at all levels recovered rapidly, with a tendency of the higher-level concentrations to recover prior to those at lower levels.

The autumn ozone concentration pattern followed that seen in spring and summer, but with a slower ozone concentration recovery in the morning (Fig. 2). Also, the onset of the concentration recovery occurred slightly later in autumn (at 09:00) than in spring and summer (between 06:00 and 08:00). These features are very likely related to the shorter daytime length in autumn compared with spring and summer (Fig. 3). The later sunrise time in autumn facilitated a prolonged deposition-dominant ozone budget and a delayed replenishment. The reduced solar radiation intensity in autumn was unable to sustain a rapid enrichment of ozone from the residual layer. Meanwhile, the photochemical production of ozone was also weakened. As a consequence, the autumn ozone profile showed a gradual concentration recovery from high to low measurement levels in the morning. Moreover, the occurrence of the ozone concentration declination in the afternoon in autumn at around 17:00, well before that in spring and summer, can be possibly ascribed to the earlier sunset time and corresponding increase in the surface layer stability. Finally, the highest ozone concentrations tended to shift upwards in heights from spring to autumn. No clear diurnal pattern in ozone concentrations was seen in winter.

\subsection{Frequencies of low ozone concentration episodes}

As described before, we defined four low-concentration thresholds $(10,5,2$, and $1 \mathrm{ppb})$ to characterize low ozone concentration episodes. When such an episode lasted for more than $30 \mathrm{~min}$, it is considered as an ozone depletion event, otherwise as an ozone drop. To assist the characterization of long-lasting depletion events longer than $3 \mathrm{~h}$, a gapfilling procedure was utilized as described in Sect. 2.3.

The observation frequency, i.e. the number of observations, of ozone concentration drops below $10 \mathrm{ppb}$ exhibited similar diurnal variations at the different measurement levels (Fig. 4). The most pronounced diurnal variation was seen inside the canopy layer $(\leq 16.8 \mathrm{~m})$, with low ozone concentrations frequently observed at 04:00-08:00 (Fig. 4a, b and c). Low ozone observations were rare around noon. The diurnal behaviour of ozone concentration drops below 5 ppb resembled those of the below $10 \mathrm{ppb}$ drops. However, excluding the $4.2 \mathrm{~m}$ measurement level, ozone concentrations below $5 \mathrm{ppb}$ occurred also often in the afternoon at around 16:0020:00. For the occurrence of ozone concentration drops below $2 \mathrm{ppb}$, in addition to the expected noon low, the diur- 
(a)

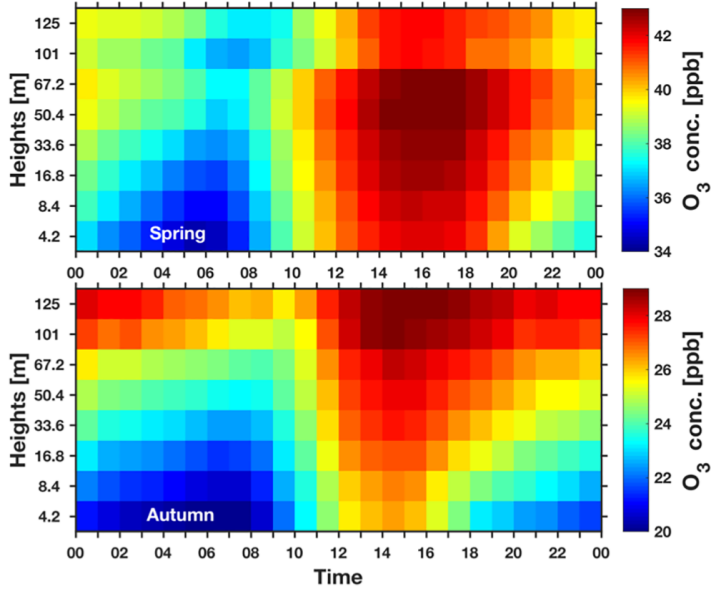

(b)

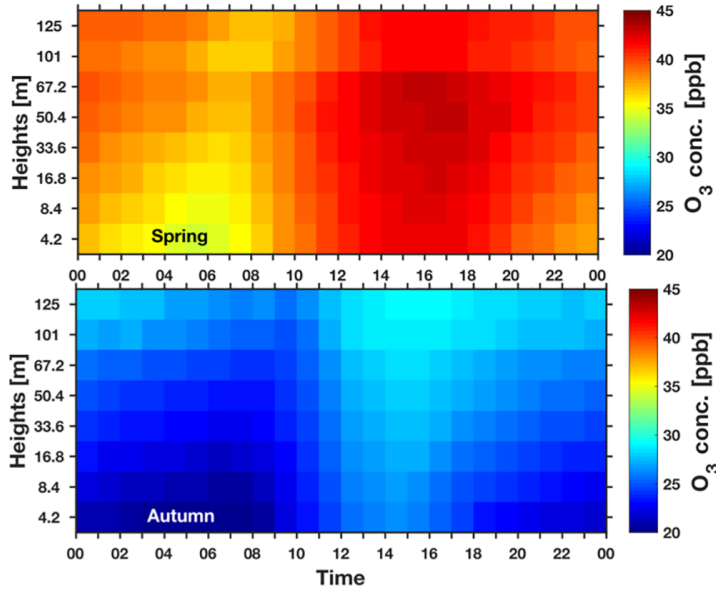

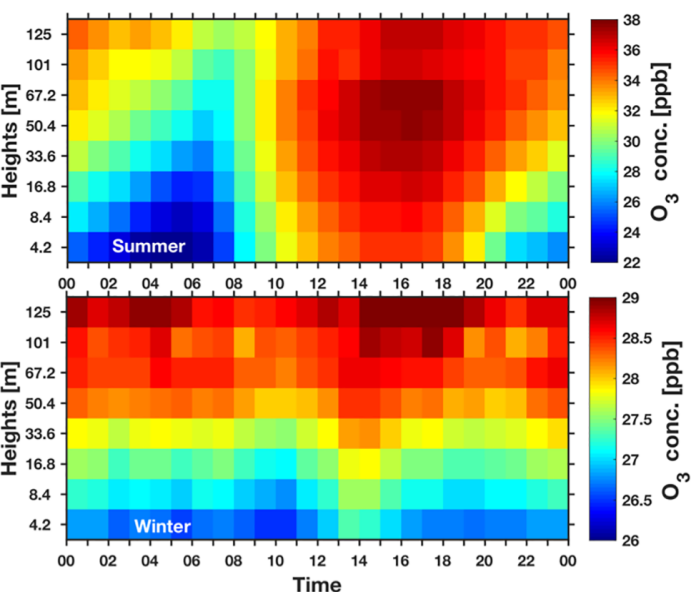

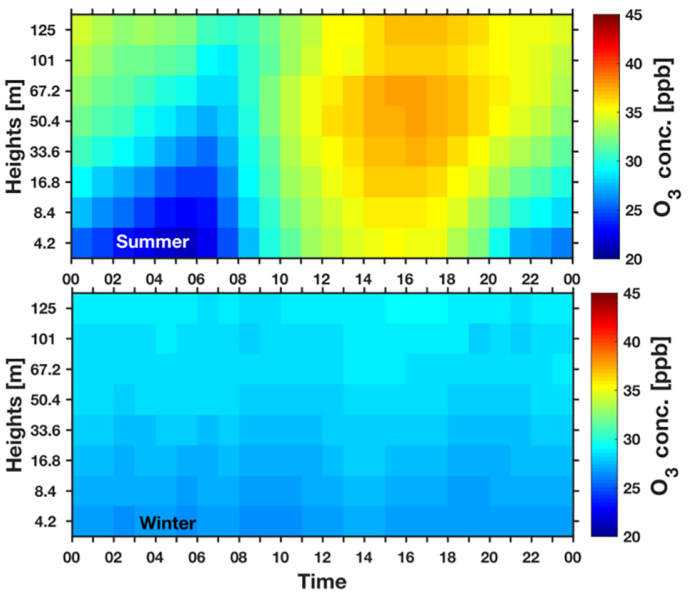

Figure 2. Diurnal profiles of ozone concentrations in different seasons. Spring: March-May, summer: June-August, autumn: SeptemberNovember, and winter: December-February. Panel (a): ozone concentrations in different scales for different seasons to emphasize the profile information. Note the significantly larger variability of $\mathrm{O}_{3}$ concentrations during summer months. Panel (b): ozone concentrations in the same scale for different seasons.

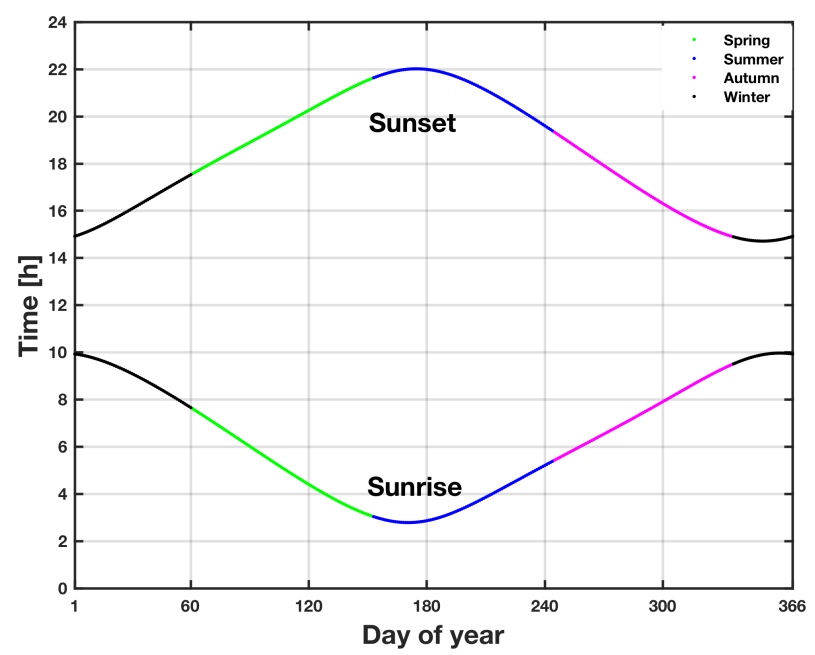

Figure 3. Estimated sunrise and sunset time of different seasons for Hyytiälä SMEAR II station $\left(61^{\circ} 51^{\prime} \mathrm{N}, 24^{\circ} 17^{\prime} \mathrm{E}, 181 \mathrm{~m}\right.$ a.s.1.). nal distribution exhibited a second trough at around 02:00 in the early morning prior to the morning high, again except at $4.2 \mathrm{~m}$. Interestingly at $4.2 \mathrm{~m}$, the moment at which the morning peak observations occurred shifted in time from 04:00 to 06:00 for the sequence of ozone concentration drops below 10,5 , and $2 \mathrm{ppb}$. This feature was also perceptible at 8.4 and $16.8 \mathrm{~m}$ (Fig. 4b and c). No systematic diurnal variations were recognized for the observation frequency of ozone concentration drops below $1 \mathrm{ppb}$.

Ozone depletion events that lasted for more than $30 \mathrm{~min}$ occurred mainly in autumn and winter (Fig. 5). March had the lowest number of ozone depletion events below $10 \mathrm{ppb}$, after which the number of these events tended to increase over the course of both months (towards December) and measurement heights (from low to high). Except in May and June, ozone depletion events below $10 \mathrm{ppb}$ were observed to reach the measurement level of $67.2 \mathrm{~m}$. Ozone depletion events below $5 \mathrm{ppb}$ were mainly observed below the canopy level ( $\leq 16.8 \mathrm{~m})$ during June-September, while only during 

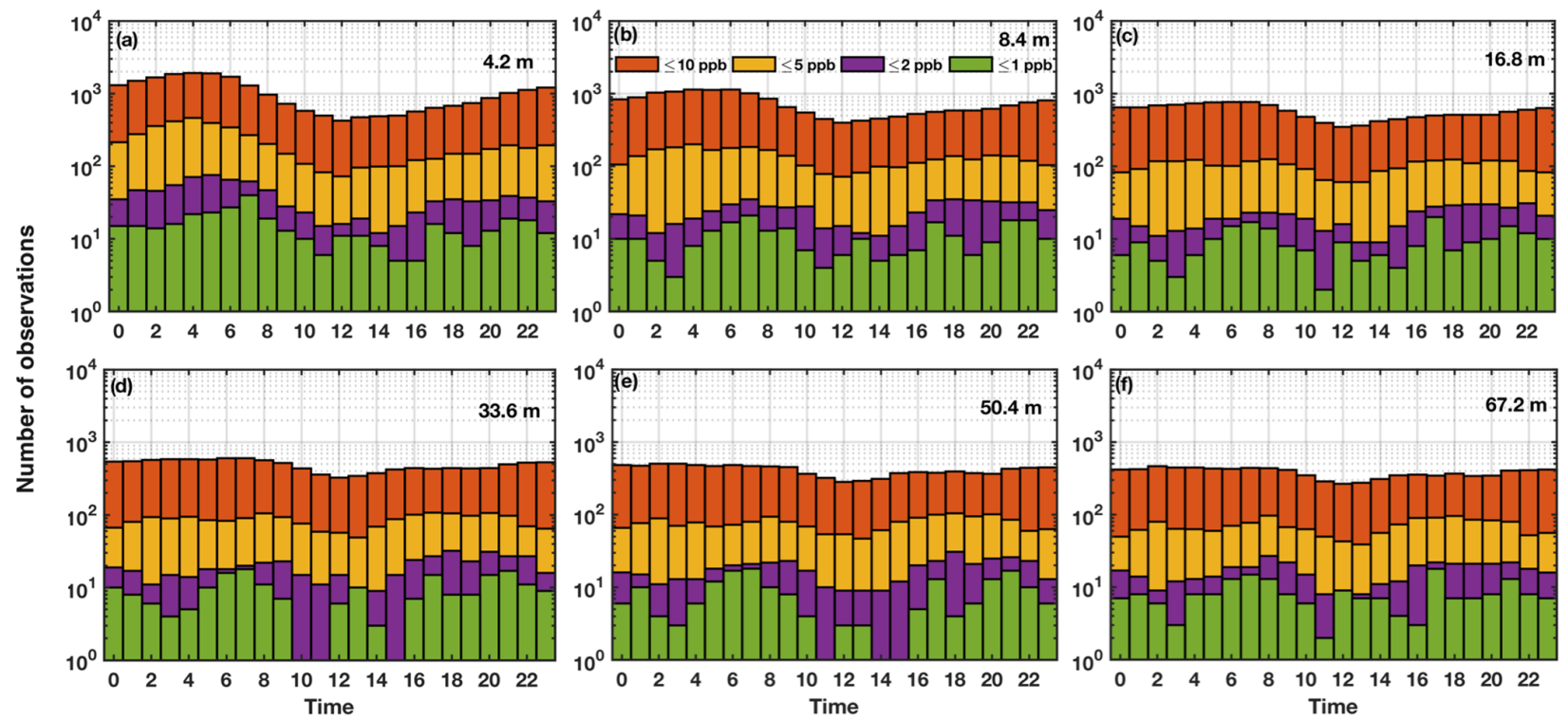

Figure 4. Hourly distribution of observations of ozone concentration drops below 10, 5, 2, and 1 ppb at different heights: (a) $4.2 \mathrm{~m}$, (b) $8.4 \mathrm{~m}$, (c) $16.8 \mathrm{~m}$, (d) $33.6 \mathrm{~m}$, (e) $50.4 \mathrm{~m}$, and (f) $67.2 \mathrm{~m}$. The statistics were based on the $10 \mathrm{~min}$ ozone data and the observation frequency is presented in the logarithmic scale.
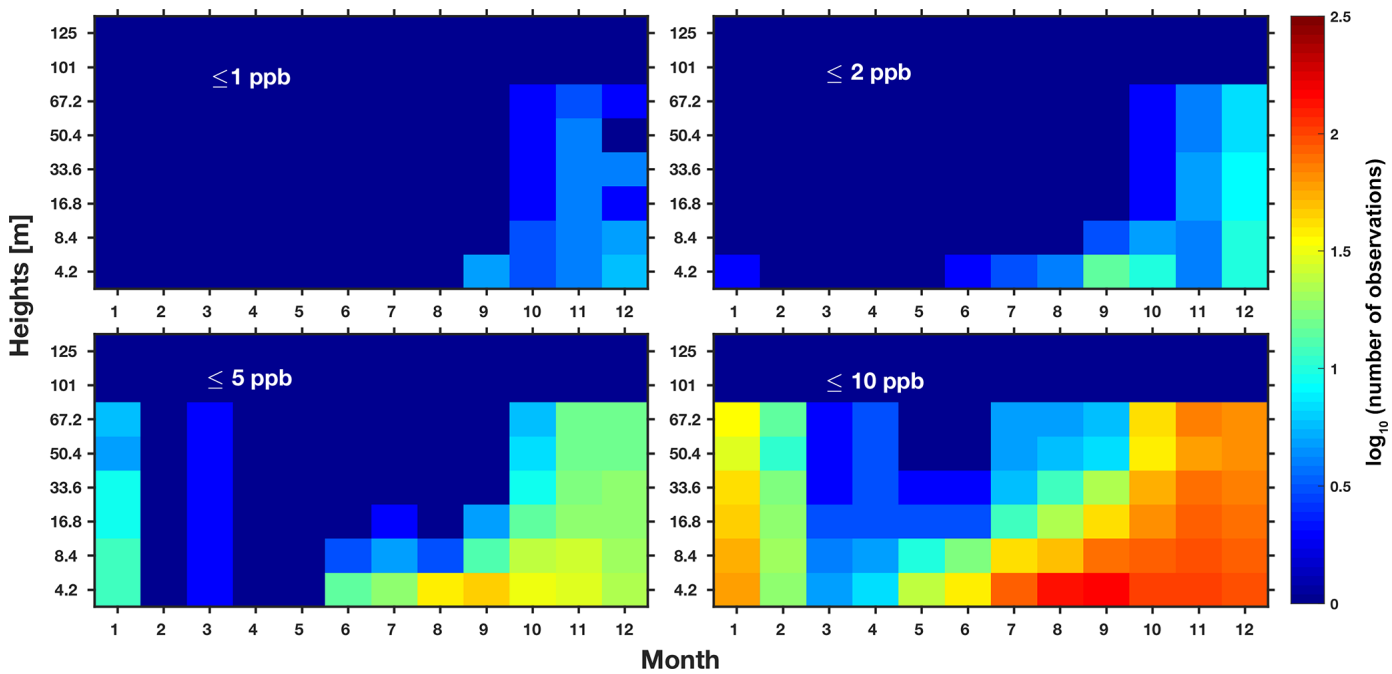

Figure 5. Vertical extension of ozone depletion events that last longer than $30 \mathrm{~min}$. The numbers of depletion event observations are colour coded in logarithmic scale for ozone concentration drops below 10, 5, 2, and $1 \mathrm{ppb}$.

October-January and in March did they reach $67.2 \mathrm{~m}$. In February, April, and May, no ozone depletion events below $5 \mathrm{ppb}$ were observed at any of the measurement levels. The below-2 ppb ozone depletion events exhibited a similar feature to the below-5 ppb events - however, with the depletion seen only at the lowest measurement level (i.e. $4.2 \mathrm{~m}$ ) in January and summer months. No depletion events below $2 \mathrm{ppb}$ were observed during February-May. The below-1 ppb depletion events were concentrated in the period of OctoberDecember.
We found a number of long-lasting ( $>3 \mathrm{~h}$ ) ozone depletion events (Table 1). During the period 1996-2016, there were four such events, in which the ozone depletion below $2 \mathrm{ppb}$ was observed up to the height of $67.2 \mathrm{~m}$. This number increased to 26 in the case of below-5 ppb depletion events and to 161 (or 148 without the gap-filling procedure) in the case of below-10 ppb events. Long-lasting ozone depletion events below $10 \mathrm{ppb}$ occurred all year around, whereas no such events below 5 ppb were observed in February, April, May, or June (Fig. 6). Long-lasting ozone depletion events below 2 ppb were found in October, November, and Decem- 
Table 1. The number of ozone depletion events seen at different heights that last for more than $3 \mathrm{~h}$. Ozone depletion events were classified as concentration drops below 10, 5, 2, and $1 \mathrm{ppb}$. The statistics were based on the original $10 \mathrm{~min}$ data. Statistics based on gap-filled data are presented in parentheses. The gap-filling procedure resulted in no significant changes in the statistics of depletion events for heights of 4.2-67.2 m.

\begin{tabular}{lrrrrrrrr}
\hline Height $(\mathrm{m})$ & 125 & 101 & 67.2 & 50.4 & 33.6 & 16.8 & 8.4 & 4.2 \\
\hline$<10 \mathrm{ppb}$ & $0(6)$ & $0(10)$ & $148(161)$ & $141(185)$ & $178(192)$ & $202(215)$ & $241(256)$ & $356(378)$ \\
$<5 \mathrm{ppb}$ & $0(1)$ & $0(1)$ & 26 & $28(32)$ & $29(31)$ & $35(37)$ & $43(47)$ & $63(67)$ \\
$<2 \mathrm{ppb}$ & 0 & 0 & 4 & 5 & 6 & 5 & 6 & 6 \\
$<1 \mathrm{ppb}$ & 0 & 0 & 1 & 1 & 1 & 1 & 2 & 2 \\
\hline
\end{tabular}
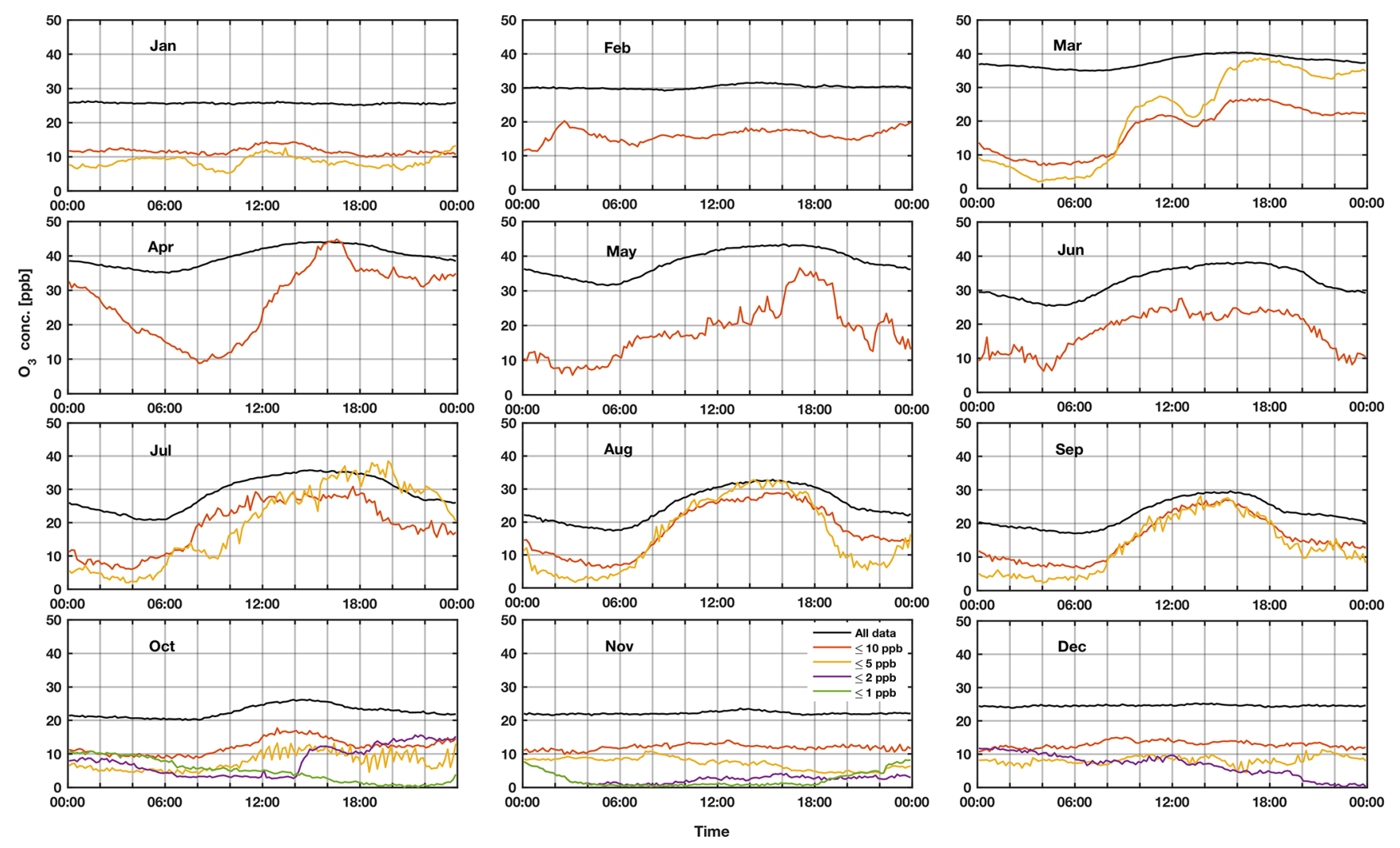

Figure 6. Diurnal patterns in median ozone concentrations at $4.2 \mathrm{~m}$ in different months, from all the data (black), from below-10 ppb depletion events (red), from below-5 ppb depletion events (orange), from below-2 ppb (purple) and from below-1 ppb (green). A minimum duration threshold of $3 \mathrm{~h}$ was used to select days with ozone depletion events, based on the gap-filled data.

ber, whereas below-1 ppb events occurred only in October and November and they were generally associated with high humidity conditions.

The variations of median diurnal ozone concentrations for different months derived from all 10 min data ranged from 17 to $45 \mathrm{ppb}$, with diurnal cycles seen in almost all months, except in January and December (black lines in Fig. 6). The median ozone concentrations obtained from the days with observations of long-lasting ozone depletion events were, in general, lower than those derived from all $10 \mathrm{~min}$ data, and displayed similar diurnal patterns to those derived from all 10 min data during May-October. No systematic diurnal behaviour was identified for any type of ozone depletion event between November and April, nor was it found for the below- 2 ppb and the below-1 ppb depletion events in October. The difference between the median ozone concentrations determined on all the days and on depletion event days was about 10-15 ppb between October and February. For JulySeptember, this concentration difference was big in the early morning, then diminished towards noon, and enlarged again after 16:00, as a result of boundary layer dynamics.

\subsection{Features in low-ozone episodes}

Ozone concentrations were, on average, lower at higher relative humidities (Fig. 7a), and low-ozone episodes were only 

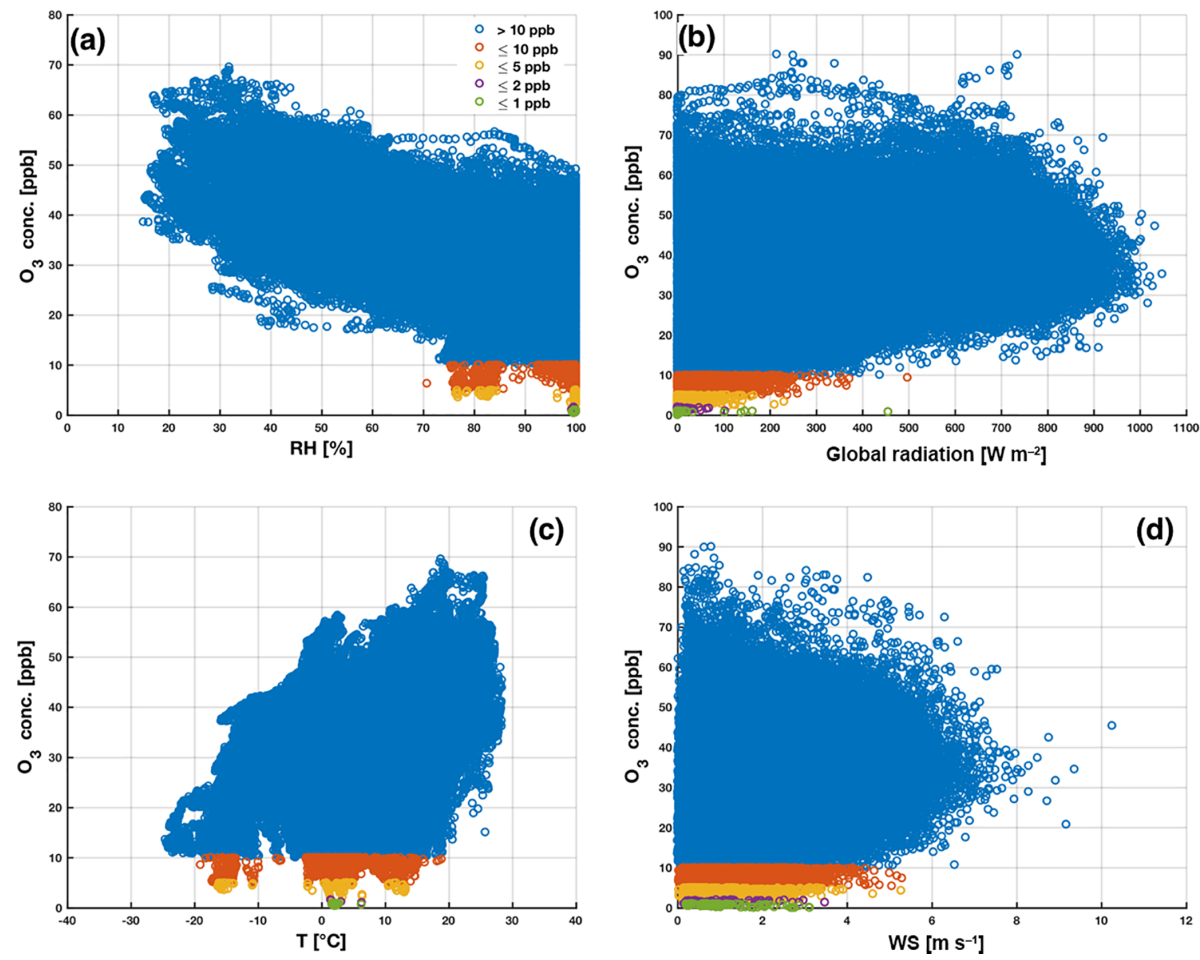

Figure 7. Ozone concentrations vs. (a) relative humidity (RH), (b) global radiation, (c) temperature ( $T$ ), and (d) wind speed. Plots are made with $10 \mathrm{~min}$ data collected from the $16.8 \mathrm{~m}$ measurement level during the period 1996-2016, with an exception of the global radiation data from $18 \mathrm{~m}$.

observed in high RH ( $>70 \%$ ) conditions. According to Altimir et al. (2006), moisture in the air enhances the total ozone deposition, possibly due to the high solubility of ozone in water (Sotelo et al., 1989). At RH levels higher than $70 \%$ almost all surfaces of foliage are covered with thin water film, which efficiently adsorbs ozone and decouples the stomatal conductance from $\mathrm{O}_{3}$ fluxes, forming a significant non-stomatal sink for ozone (Altimir et al. 2006). This can be responsible for about $40-60 \%$ of the observed decrease in $\mathrm{O}_{3}$ concentrations in the very humid cases in our data, and we can conclude that moisture content in the air is likely to be one of the key factors controlling these low-ozone episodes. Low ozone concentrations occurred mostly during the nighttime, associated with little global radiation (Fig. 7b) and low wind speeds (Fig. 7d). Air temperatures have been reported to have a minor effect on the total ozone deposition (Rannik et al., 2012). Although we observed no direct relationship between air temperature and ozone concentration drops (Fig. 7c), the temperature might indirectly affect ozone deposition by influencing e.g. the RH.

When ozone concentration dropped lower than 1 or $2 \mathrm{ppb}$ at $67.2 \mathrm{~m}$, there was typically a very small ozone concentration difference between the 67.2 and $4.2 \mathrm{~m}$ heights, i.e. no gradient in the vertical ozone concentration profile. These episodes were found in association with friction velocities between 0 and $1 \mathrm{~m} \mathrm{~s}^{-1}$, which indicates relatively stable con- ditions with low vertical mixing. Small ozone gradients were mainly observed at low friction velocities (Fig. 8a). This is consistent with the observation, depicted in Fig. 7b, that most of the low ozone concentrations occurred under relatively dark conditions with low solar radiation. Ozone concentration below 5 or $10 \mathrm{ppb}$ observed at $67.2 \mathrm{~m}$ occurred mostly when the potential temperature difference between the 67.2 and $4.2 \mathrm{~m}$ heights was around $0{ }^{\circ} \mathrm{C}$ (Fig. 8b), indicating neutral atmospheric conditions. Under such conditions, the atmosphere does not favour large-scale vertical mixing of ozone, yet small-scale turbulent eddies could be formed, aiding the deposition of ozone and leading to the occurrence of ozone concentration drops.

In addition, there existed a number of cases in which the $4.2 \mathrm{~m}$ ozone concentration was low while the concentration difference between 67.2 and $4.2 \mathrm{~m}$ was large (Fig. 9a) - i.e. a gradient in the vertical ozone concentration profile. These episodes were also observed at very low friction velocities (Fig. 8c), but they tended to exhibit larger concentration differences at larger differences in the potential temperature between 67.2 and $4.2 \mathrm{~m}$ (Fig. 8d). Such observations likely indicate that the gradients in the vertical ozone concentration profile occurred under calm and stably stratified conditions. The narrow range of the low friction velocities $(0$ $0.5 \mathrm{~m} \mathrm{~s}^{-1}$ ) observed during these cases may suggest a nearly invariant deposition sink for ozone. In such circumstances, 

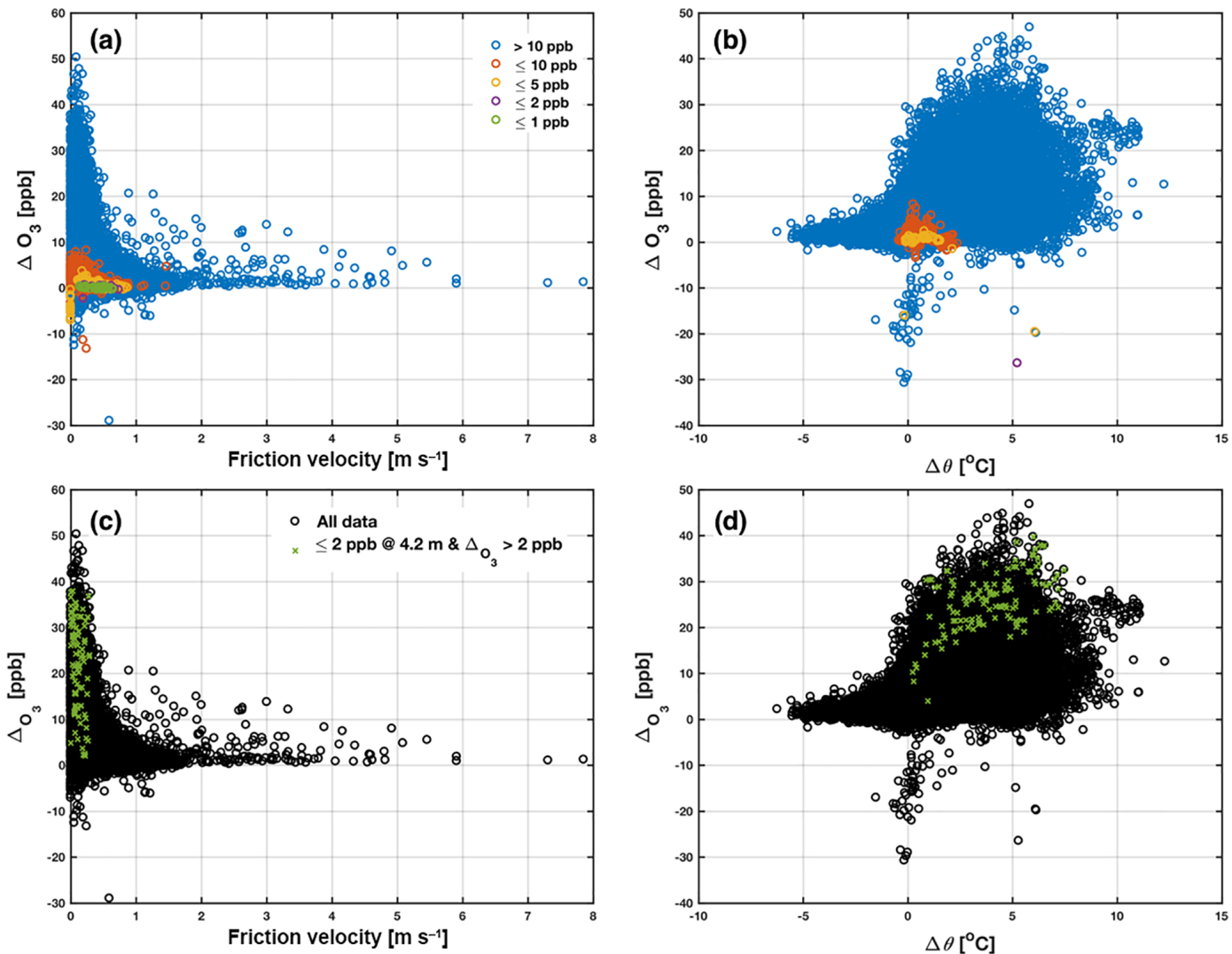

Figure 8. Ozone concentration difference between 67.2 and $4.2 \mathrm{~m}$ measurement levels vs. (a, c) friction velocity determined at $23.3 \mathrm{~m}$ and (b, d) potential temperature difference between 67.2 and $4.2 \mathrm{~m}$ measurement levels. The colour codes in (a, b) represent concentration drops below 10, 5, 2, and $1 \mathrm{ppb}$ from the ozone measurement at $67.2 \mathrm{~m}$. The green crosses in (c, d) mark the data points fulfilling the conditions that the ozone concentration at $4.2 \mathrm{~m}$ is smaller than $2 \mathrm{ppb}$, while the difference in the ozone concentration between 67.2 and $4.2 \mathrm{~m}$ is larger than $2 \mathrm{ppb}$.

the smaller the mixing height, the more effective the loss of surface ozone that can be expected, due to the lack of ozone replenishment from higher up, which possibly results in the occurrence of the large number of ozone depletion events only at lower heights (over 200 below-10 ppb events at the three lowest heights, Table 1).

Based on the above-described features in the vertical ozone concentration profile, two major types of ozone depletion events were identified: (1) the ozone depletion occurred at low measurement levels only with a clear gradient in the vertical ozone profile, termed here as near-surface depletion, and (2) the ozone depletion extended to $67.2 \mathrm{~m}$ with a negligible ozone concentration difference between 67.2 and $4.2 \mathrm{~m}$, termed here as full-profile depletion (Fig. 9a, c and d). A possible third type lies in between the near-surface and full-profile depletion, in which decreases in ozone concentration could be seen at high measurement levels but with a remarkable difference in the ozone concentration between 67.2 and $4.2 \mathrm{~m}$, and a clear gradient can be seen through the vertical concentration profile. This third type is referred to as gradient-profile ozone depletion. However, the boundary between the gradient-profile and the near-surface depletion can often be vague in ambient data, i.e. a depletion event classified as a near-surface event may be re-categorized as the gradient-profile type if a longer period is considered when a decrease trend in high-level ozone concentrations can be seen. During the years 1996-2016, over a hundred fullprofile below-10 ppb depletion events were observed, with 26 below-5 ppb events, four below- 2 ppb events, and even one below-1 ppb event (Table 2). We define that a near-surface depletion event should fulfil two criteria: (1) the first quartile of the difference in the ozone concentration between $67.2 \mathrm{~m}$ and the height that the depletion reaches has a value larger than $2 \mathrm{ppb}$, and (2) the third quartile of the ozone concentration measured at $67.2 \mathrm{~m}$ during the depletion event is larger than $10 \mathrm{ppb}$. Then seven below-10 ppb events lasting longer than $3 \mathrm{~h}$ with depletion reaching $33.6 \mathrm{~m}$ were identified during our study period (Table 2).

The near-surface and the gradient-profile ozone depletion events were observed throughout the year, except in spring, with more pronounced ozone gradients typically seen in later summer and autumn (Fig. 9b). However, the full-profile de- 

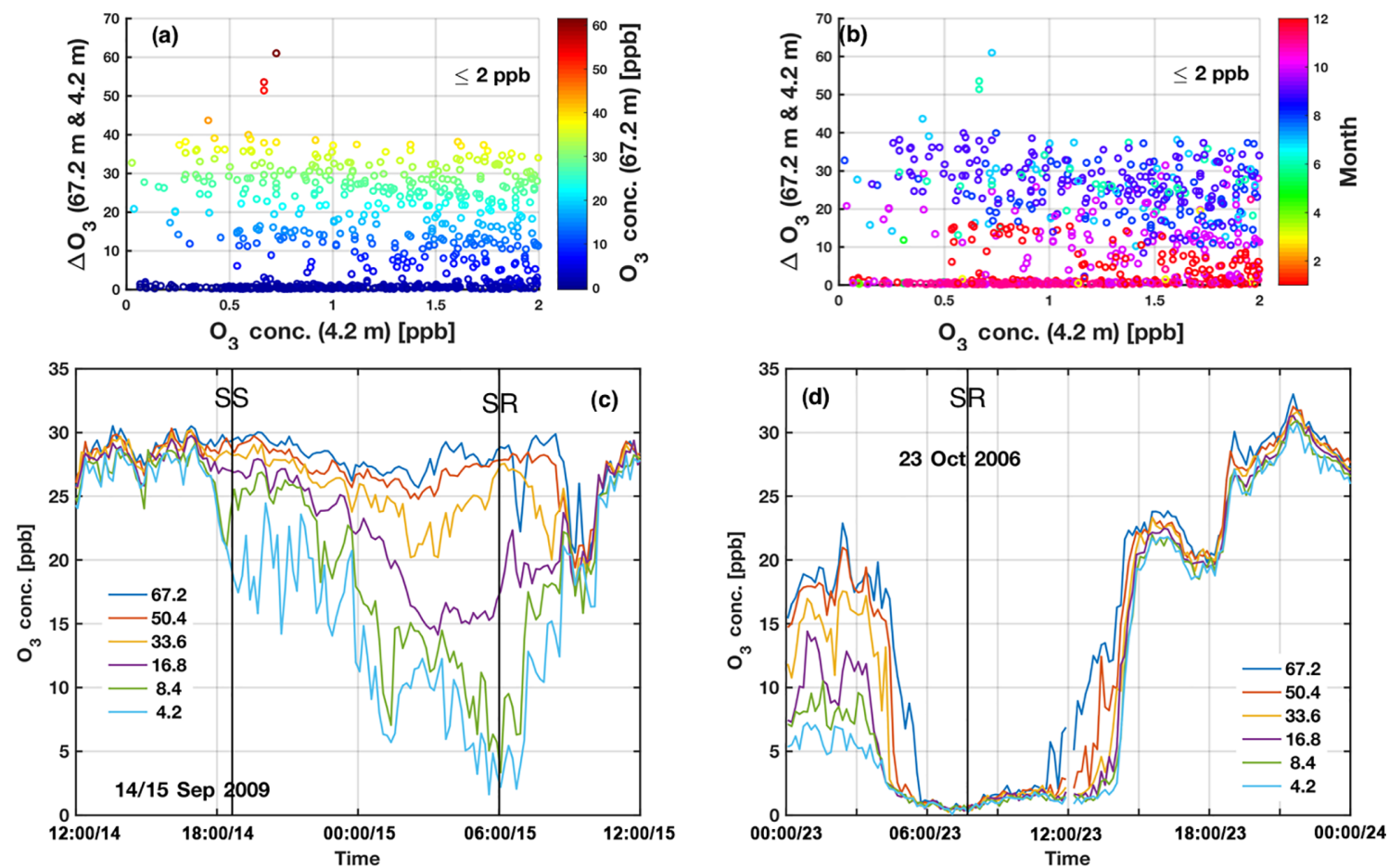

Figure 9. The ozone concentration difference between 67.2 and $4.2 \mathrm{~m}$ vs. the ozone concentration $(\leq 2 \mathrm{ppb})$ at $4.2 \mathrm{~m}$, (a) colour-coded by ozone concentrations at $67.2 \mathrm{~m}$ and (b) colour-coded by month. (c) A near-surface depletion event on 14-15 September, 2009. (d) A full-profile depletion event on 23 October 2006. The vertical black lines indicate the sunrise (SR) and sunset (SS) times.

Table 2. The number of full-profile and near-surface ozone depletion events that last for more than $3 \mathrm{~h}$. Since the two highest measurement levels (101 and $125 \mathrm{~m}$ ) were introduced in February 2013 only, the statistics for the full-profile depletion events shown here are based on measurements at $67.2 \mathrm{~m}$ and lower heights. The statistics were based on the original $10 \mathrm{~min}$ data. Statistics based on gap-filled data are presented in parentheses.

\begin{tabular}{lrrrrrr}
\hline Depletion event types & Full-profile $^{\mathrm{a}}$ & \multicolumn{5}{c}{ Near-surface $^{\mathrm{b}}$} \\
\cline { 3 - 7 } Height $(\mathrm{m})$ & 67.2 & 50.4 & 33.6 & 16.8 & 8.4 & 4.2 \\
\hline$<10 \mathrm{ppb}$ & $120(125)$ & 0 & 7 & 26 & $98(100)$ & $160(164)$ \\
$<5 \mathrm{ppb}$ & 26 & 0 & 1 & 3 & 6 & $13(14)$ \\
$<2 \mathrm{ppb}$ & 4 & 0 & 0 & 0 & 1 & 1 \\
$<1 \mathrm{ppb}$ & 1 & 0 & 0 & 0 & 0 & 0 \\
\hline
\end{tabular}

${ }^{a}$ Full-profile ozone depletion events here are determined using the third quartile of the difference in the ozone concentration between 67.2 and $4.2 \mathrm{~m}$, which has a value smaller than $2 \mathrm{ppb}$.

${ }^{\mathrm{b}}$ Near-surface ozone depletion events here are determined using the first quartile of the difference in the ozone concentration between $67.2 \mathrm{~m}$ and the height that the depletion reaches, which has a value larger than $2 \mathrm{ppb}$. Meanwhile, the third quartile of the ozone concentration measured at $67.2 \mathrm{~m}$ during the depletion event is larger than $10 \mathrm{ppb}$.

pletion events were primarily observed in winter months (Fig. 9b). The near-surface depletion events, though often observed at night and early morning hours under relatively dark conditions, were not exclusively restricted in this time window. Occasionally, they also occurred during daytime hours - presumably when a stable condition prevails resulting in a low mixing height.

An analysis of atmospheric conditions was carried out for a near-surface depletion event encountered during the night of 14-15 September 2009 (Fig. 9c), and for a full-profile de- pletion event that took place on the morning of 23 October 2006 (Fig. 9d). The near-surface depletion event was initiated before the sunset on 14 September and lasted over the course of the night. However, during the $2-3 \mathrm{~h}$ prior to the sunrise, unlike the ozone concentrations at 4.2 and $8.4 \mathrm{~m}$ showing a continuous decrease, the ozone concentration at $16.8 \mathrm{~m}$ (about the forest canopy height) tended to level out. This observation is likely ascribed to the formation of two decoupling layers above and below the forest canopy. Upon sunrise, the ozone concentrations at 4.2 and $8.4 \mathrm{~m}$ started shortly 
to recover from their lowest levels, while an instantaneous concentration recovery was possibly seen at $16.8 \mathrm{~m}$, accompanied by a decrease in the $33.6 \mathrm{~m}$ ozone concentration. These phenomena indicate a rapid development of turbulent mixing vertically above the canopy level. But the break-up of the decoupling and the extension of the mixing height to $67.2 \mathrm{~m}$ came with some time lags. Interestingly, after the ozone concentration levels at different heights converged at around 09:00, there seems to be a transient obstruction in the further increase of ozone concentrations below $16.8 \mathrm{~m}$. The ozone concentrations at $16.8 \mathrm{~m}$ and higher nearly levelled out until 10:00, while the 8.4 and $4.2 \mathrm{~m}$ concentrations showed a drop before a concentration increase was perceptible. Such a feature (in some cases, even a clear reduction in the ozone concentrations measured at all heights) can be seen in more than $30 \%$ of the below-10 ppb near-surface depletion events at $4.2 \mathrm{~m}$. These phenomena might be attributed to the ozone loss via photolysis and other consumptions through chemical reactions. In contrast, the full-profile event on 23 October 2006 occurred before sunrise and lasted through the morning hours, even until almost 14:00 at $4.2 \mathrm{~m}$. The recovery of the ozone concentrations was first seen at $67.2 \mathrm{~m}$ before noon and then gradually at lower heights.

Both near-surface and full-profile depletion events displayed distinct features in relation to the air temperature (Fig. 10a-1). While both depletion events were observed at low-temperature conditions, a temperature gradient was only present during the near-surface depletion event, with higher temperatures found at the highest measurement levels. This observation shows that this near-surface depletion event occurred during a temperature inversion. A similar feature was identifiable during another depletion episode on the early morning of 14 September 2010 (Fig. 10a), with very low wind speeds at the low measurement levels and mild turbulent conditions at the high measurement levels (Fig. 10c). In contrast, calm conditions were present during the full-profile ozone depletion event observed on October 2006 (Fig. 10i).

Humid conditions have been previously reported to favour the occurrence of low ozone concentrations (Altimir et al., 2006). During both near-surface and full-profile ozone depletion events, the relative humidity was high (Fig. 10b, h). The results obtained here thus indicate that the ozone depletion at this relatively clean boreal forest site tends to occur under low-mixing calm conditions with a high moisture content in the air (as can be seen in Fig. 10c, d, i, j). Similar low-mixing conditions have been observed previously in association with polar boundary layer ozone depletion events (Simpson et al., 2007; Cao et al., 2016), but no relation to $\mathrm{RH}$, as found in our observations, was reported in the polar region (note that polar ozone depletion is characterized by halogen chemistry, which has not been observed at our boreal forest site).

In addition, it seems that an elevated $\mathrm{CO}$ concentration is a potential indicator of a full-profile depletion (Fig. 10k), since low ozone concentrations were found in association with high $\mathrm{CO}$ concentrations. The recovery of ozone concentrations from the depletion event was observed first at high measurement levels, and at about the same time the $\mathrm{CO}$ concentration began to decrease. However, no clear trace of such a feature was seen in the near-surface depletion case, though the highest $\mathrm{CO}$ concentrations seemed to coincide with the lowest ozone concentrations (Fig. 10e). The relation between the ozone depletion and $\mathrm{NO}_{x}$ concentration was also inspected (Fig. 10f, 1), but no systematic connection that could explain our observations was found.

\section{Conclusions}

Here, we have investigated vertical profiles of ozone concentrations inside and above a conifer stand over a period of 20 years (1996-2016) in a boreal forest environment in southern Finland (the SMEAR II station). The variations in ozone concentrations were investigated in relation to other measured trace gases and meteorological variables. Our results show that, in general, ozone concentrations increased with an increasing height above the ground. The daily median ozone concentrations at our measurement site were found to be in the range of about $20-50 \mathrm{ppb}$, with clear maxima in the springtime.

Temporal significant decreases of ozone concentrations at the ground level have been observed in very polluted urban environments (US National Research Council, 1992; Gregg et al., 2003). However, to our knowledge and based on observations, the occurrence of very low ozone concentrations in relatively clean environments other than the polar regions has not been reported previously. The main aim of our study was to establish the frequency and strength of ozone depletion events at our boreal forest site. By analysing 20 years of ozone measurements, we identified on average more than a thousand of $10 \mathrm{~min}$-periods at $4.2 \mathrm{~m}$, during which ozone concentrations were below $10 \mathrm{ppb}$, and a few tens of cases of ozone concentration below $2 \mathrm{ppb}$. These low ozone concentration episodes occurred typically at low temperature, low wind speed, high RH, and limited intensity of solar radiation, which are conditions likely related to the formation of a shallow mixing layer. When such conditions prevail, neither photochemical production nor enrichment from the residual layer can provide sufficient replenishment of ozone into the confined mixing layer, while ozone loss through deposition and chemical consumption continued unperturbed.

Future investigations should relate ozone depletion to ozone chemistry and boundary layer dynamics in order to understand the underlying mechanisms involved in these particular events. In addition, it is worth exploring whether there is a connection between ozone depletion and atmospheric new particle formation. It seems that several unrevealed or at least rarely observed processes are likely to take place during ozone depletion events in clean to moderately polluted environments. 

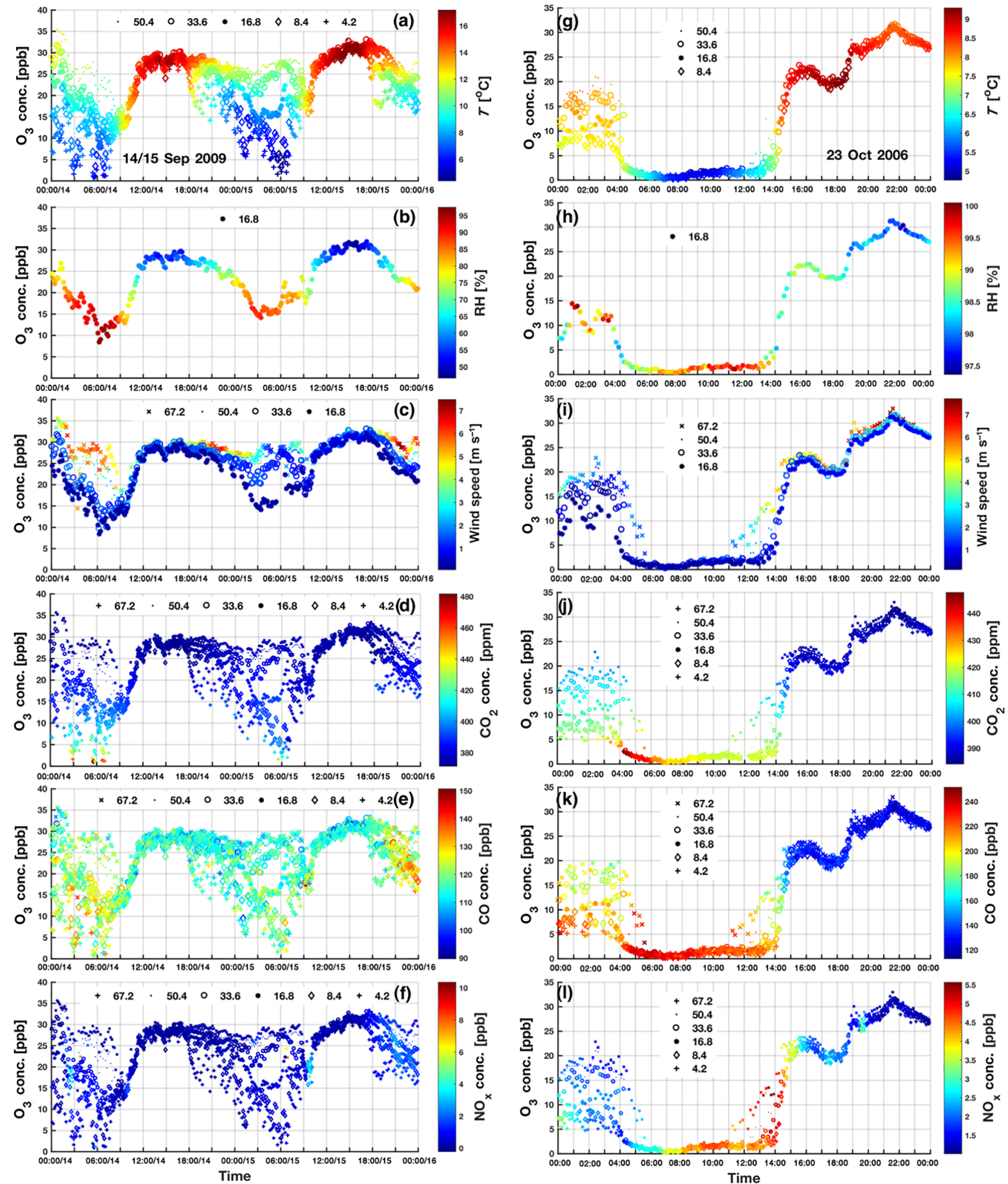

Figure 10. The influence of $(\mathbf{a}, \mathbf{g})$ air temperature $(T),(\mathbf{b}, \mathbf{h})$ relative humidity $(\mathrm{RH}),(\mathbf{c}, \mathbf{i})$ wind speed, $(\mathbf{d}, \mathbf{j})$ carbon dioxide $\left(\mathrm{CO}_{2}\right)$ concentration $(\mathbf{e}, \mathbf{k})$ carbon monoxide $(\mathrm{CO})$ concentration, and $(\mathbf{f}, \mathbf{l})$ nitrogen oxides $\left(\mathrm{NO}_{x}\right)$ concentrations on the evolvement of the ozone concentration along time. Left column: a near-surface depletion event on 14-15 September 2009. Right column: a full-profile depletion event on 23 October 2006. 
Data availability. The data used in this work were collected at Hyytiälä SMEAR II station, which are available in the SmartSMEAR database (https://avaa.tdata.fi/web/smart/smear/).

Competing interests. The authors declare that they have no conflict of interest.

Special issue statement. This article is part of the special issue "Pan-Eurasian Experiment (PEEX)". It does not belong to a conference.

Acknowledgements. This work was supported by the Academy of Finland Centre of Excellence (projects no. 272041 and 1118615), the European Union's Horizon 2020 research and innovation programme under grant agreement no. 654109 (ACTRIS-2) and the European Union Seventh Framework Programme (FP7/2007-2013 ACTRIS under grant agreement no. 262254). Matti P. Rissanen acknowledges the Academy of Finland (project no. 299574). Xuemeng Chen appreciates gratefully the Doctoral Programme in Atmospheric Sciences (ATM-DP, University of Helsinki) for financial support. Lauriane L. J. Quéléver expresses gratitude to the COALA project (grant no. 638703) funded by the European Research Council. Also the help of Pasi Kolari, Stephany Buenrostro Mazon, and students participating in the 2016 Autumn School in Physics, Chemistry and Biology of Air Pollution and their Effects is acknowledged.

Edited by: Dominick Spracklen

Reviewed by: two anonymous referees

\section{References}

Altimir, N., Kolari, P., Tuovinen, J.-P., Vesala, T., Bäck, J., Suni, T., Kulmala, M., and Hari, P.: Foliage surface ozone deposition: a role for surface moisture?, Biogeosciences, 3, 209-228, https://doi.org/10.5194/bg-3-209-2006, 2006.

Ashmore, M. R.: Assessing the future global impacts of ozone on vegetation, Plant Cell Environ., 28, 949-964, https://doi.org/10.1111/j.1365-3040.2005.01341.x, 2005.

Atkinson, R. and Arey, J.: Atmospheric Degradation of Volatile Organic Compounds, Chem. Rev., 103, 4605-4638, https://doi.org/10.1021/cr0206420, 2003.

Atlas, E. L., Ridley, B. A., and Cantrell, C. A.: The Tropospheric Ozone Production about the Spring Equinox (TOPSE) Experiment: Introduction, J. Geophys. Res., 108, 8353, https://doi.org/10.1029/2002jd003172, 2003.

Brown, S. S. and Stutz, J.: Nighttime radical observations and chemistry, Chem. Soc. Rev., 41, 6405-6447, https://doi.org/10.1039/c2cs35181a, 2012.

Cao, L., Platt, U., and Gutheil, E.: Role of the boundary layer in the occurrence and termination of the tropospheric ozone depletion events in polar spring, Atmos. Environ., 132, 98-110, https://doi.org/10.1016/j.atmosenv.2016.02.034, 2016.
Clifton, O. E., Fiore, A. M., Munger, J. W., Malyshev, S., Horowitz, L. W., Shevliakova, E., Paulot, F., Murray, L. T., and Griffin, K. L.: Interannual variability in ozone removal by a temperate deciduous forest, Geophys. Res. Lett., 44, 542-552, https://doi.org/10.1002/2016gl070923, 2017.

Dibb, J. E., Talbot, R. W., Scheuer, E., Seid, G., and DeBell, L.: Stratospheric influence on the northern North American free troposphere during TOPSE: 7Be as a stratospheric tracer, J. Geophys. Res., 108, 8363, https://doi.org/10.1029/2001JD001347, 2003.

Ehn, M., Thornton, J. A., Kleist, E., Sipila, M., Junninen, H., Pullinen, I., Springer, M., Rubach, F., Tillmann, R., Lee, B., Lopez-Hilfiker, F., Andres, S., Acir, I. H., Rissanen, M., Jokinen, T., Schobesberger, S., Kangasluoma, J., Kontkanen, J., Nieminen, T., Kurten, T., Nielsen, L. B., Jorgensen, S., Kjaergaard, H. G., Canagaratna, M., Maso, M. D., Berndt, T., Petaja, T., Wahner, A., Kerminen, V. M., Kulmala, M., Worsnop, D. R., Wildt, J., and Mentel, T. F.: A large source of lowvolatility secondary organic aerosol, Nature, 506, 476-479, https://doi.org/10.1038/nature13032, 2014.

Emberson, L. D., Ashmore, M. R., Murray, F., Kuylenstierna, J. C. I., Percy, K. E., Izuta, T., Zheng, Y., Shimizu, H., Sheu, B. H., Liu, C. P., Agrawal, M., Wahid, A., Abdel-Latif, N. M., van Tienhoven, M., de Baruer, L. I., and Domingos, M.: Impacts of air pollutants on vegetation in developing countries, Water Air Soil Poll., 130, 107-118, https://doi.org/10.1023/A:1012251503358, 2001.

Feng, Z. and Kobayashi, K.: Assessing the impacts of current and future concentrations of surface ozone on crop yield with meta-analysis, Atmos. Environ., 43, 1510-1519, https://doi.org/10.1016/j.atmosenv.2008.11.033, 2009.

Fuentes, J. D., Gillespie, T. J., Den Hartog, G., and Neumann, H. H.: Ozone deposition onto a deciduous forest during dry and wet conditions, Agr. Forest Meteorol., 62, 1-18, https://doi.org/10.1016/0168-1923(92)90002-L, 1992.

Gregg, J. W., Jones, C. G., and Dawson, T. E.: Urbanization effects on tree growth in the vicinity of New York City, Nature, 424, 183-187, https://doi.org/10.1038/nature01728, 2003.

Hakola, H., Hellén, H., Hemmilä, M., Rinne, J., and Kulmala, M.: In situ measurements of volatile organic compounds in a boreal forest, Atmos. Chem. Phys., 12, 11665-11678, https://doi.org/10.5194/acp-12-11665-2012, 2012.

Hari, P. and Kulmala, M.: Station for measuring ecosystematmosphere relations (SMEAR II), Boreal Environ. Res., 10, 315-322, 2005.

Ilvesniemi, H., Levula, J., Ojansuu, R., Kolari, P., Kulmala, L., Pumpanen, J., Launiainen, S., Vesala, T., and Nikinmaa, E.: Long-term measurements of the carbon balance of a boreal Scots pine dominated forest ecosystem, Boreal Environ. Res., 14, 731753, 2009.

Kulmala, M., Toivonen, A., Kelä, J. M. M., and Laaksonen, A.: Analysis of the growth of nucleation mode particles observed in Boreal forest, Tellus B, 50, 449-462, https://doi.org/10.3402/tellusb.v50i5.16229, 1998.

Liu, S. C., Trainer, M., Fehsenfeld, F. C., Parrish, D. D., Williams, E. J., Fahey, D. W., Hobler, G., and Murphy, P. C.: Ozone Productionin the Rural Troposphereand the Implications for Regional and Global Ozone Distributions, J. Geophys. Res., 92, 41914207, https://doi.org/10.1029/JD092iD04p04191, 1987. 
Molina, M. J. and Rowland, F. S.: Stratospheric sink for chlorofluoromethanes: chlorine atomc-atalysed destruction of ozone, Nature, 249, 810-812, https://doi.org/10.1038/249810a0, 1974.

Monks, P. S.: Gas-phase radical chemistry in the troposphere, Chem. Soc. Rev., 34, 376-395, https://doi.org/10.1039/b307982c, 2005.

Monks, P. S., Archibald, A. T., Colette, A., Cooper, O., Coyle, M., Derwent, R., Fowler, D., Granier, C., Law, K. S., Mills, G. E., Stevenson, D. S., Tarasova, O., Thouret, V., von Schneidemesser, E., Sommariva, R., Wild, O., and Williams, M. L.: Tropospheric ozone and its precursors from the urban to the global scale from air quality to short-lived climate forcer, Atmos. Chem. Phys., 15, 8889-8973, https://doi.org/10.5194/acp-15-8889-2015, 2015.

Monteith, J. L. and Unsworth, M. H.: Principles of Environmental Physics, Plants, Animals, and the Atmosphere, 4th Edn., Edward Arnold Publishers Ltd., London, UK, 2013.

Oltmans, S. J., Lefohn, A. S., Harris, J. M., Galbally, I., Scheel, H. E., Bodeker, G., Brunke, E., Claude, H., Tarasick, D., Johnson, B. J., Simmonds, P., Shadwick, D., Anlauf, K., Hayden, K., Schmidlin, F., Fujimoto, T., Akagi, K., Meyer, C., Nichol, S., Davies, J., Redondas, A., and Cuevas, E.: Long-term changes in tropospheric ozone, Atmos. Environ., 40, 3156-3173, https://doi.org/10.1016/j.atmosenv.2006.01.029, 2006.

Pacifico, F., Folberth, G. A., Sitch, S., Haywood, J. M., Rizzo, L. V., Malavelle, F. F., and Artaxo, P.: Biomass burning related ozone damage on vegetation over the Amazon forest: a model sensitivity study, Atmos. Chem. Phys., 15, 2791-2804, https://doi.org/10.5194/acp-15-2791-2015, 2015.

Parrish, D. D., Law, K. S., Staehelin, J., Derwent, R., Cooper, O. R., Tanimoto, H., Volz-Thomas, A., Gilge, S., Scheel, H. E., Steinbacher, M., and Chan, E.: Lower tropospheric ozone at northern midlatitudes: Changing seasonal cycle, Geophys. Res. Lett., 40, 1631-1636, https://doi.org/10.1002/grl.50303, 2013.

Rannik, Ü., Altimir, N., Mammarella, I., Bäck, J., Rinne, J., Ruuskanen, T. M., Hari, P., Vesala, T., and Kulmala, M.: Ozone deposition into a boreal forest over a decade of observations: evaluating deposition partitioning and driving variables, Atmos. Chem. Phys., 12, 12165-12182, https://doi.org/10.5194/acp-1212165-2012, 2012.

Rissanen, M. P., Kurtén, T., Sipilä, M., Thornton, J. A., Kangasluoma, J., Sarnela, N., Junninen, H., Jørgensen, S., Schallhart, S., Kajos, M. K., Taipale, R., Springer, M., Mentel, T. F., Ruuskanen, T., Petäjä, T., Worsnop, D. R., Kjaergaard, H. G., and Ehn, M.: The formation of highly oxidized multifunctional products in the ozonolysis of cyclohexene, J. Am. Chem. Soc., 136, 1559615606, https://doi.org/10.1021/ja507146s, 2014.

Riuttanen, L., Hulkkonen, M., Dal Maso, M., Junninen, H., and Kulmala, M.: Trajectory analysis of atmospheric transport of fine particles, $\mathrm{SO}_{2}, \mathrm{NO}_{x}$ and $\mathrm{O}_{3}$ to the SMEAR II station in Finland in 1996-2008, Atmos. Chem. Phys., 13, 2153-2164, https://doi.org/10.5194/acp-13-2153-2013, 2013.

Rummel, U., Ammann, C., Kirkman, G. A., Moura, M. A. L., Foken, T., Andreae, M. O., and Meixner, F. X.: Seasonal variation of ozone deposition to a tropical rain forest in southwest Amazonia, Atmos. Chem. Phys., 7, 5415-5435, https://doi.org/10.5194/acp7-5415-2007, 2007.

Shang, Y., Sun, Z., Cao, J., Wang, X., Zhong, L., Bi, X., Li, H., Liu, W., Zhu, T., and Huang, W.: Systematic review of Chinese studies of short-term exposure to air pollution and daily mortality, Environ. Int., 54, 100-111, https://doi.org/10.1016/j.envint.2013.01.010, 2013.

Sillman, S.: The relation between ozone, $\mathrm{NO}_{x}$ and hydrocarbons in urban and polluted rural environments, Atmos. Environ., 33, 1821-1845, https://doi.org/10.1016/S1352-2310(98)003458, 1999.

Sillman, S., Logan, J. A., and Wofsy, A. C.: The Sensitivity of Ozone to Nitrogen Oxides and Hydrocarbons in Regional Ozone Episodes, J. Geophys. Res., 95, 1837-1851, https://doi.org/10.1029/JD095iD02p01837, 1990.

Simpson, W. R., von Glasow, R., Riedel, K., Anderson, P., Ariya, P., Bottenheim, J., Burrows, J., Carpenter, L. J., Frieß, U., Goodsite, M. E., Heard, D., Hutterli, M., Jacobi, H.-W., Kaleschke, L., Neff, B., Plane, J., Platt, U., Richter, A., Roscoe, H., Sander, R., Shepson, P., Sodeau, J., Steffen, A., Wagner, T., and Wolff, E.: Halogens and their role in polar boundary-layer ozone depletion, Atmos. Chem. Phys., 7, 4375-4418, https://doi.org/10.5194/acp7-4375-2007, 2007.

Solomon, S.: Stratospheric Ozone Depletion: A Review Of Concepts And History, Rev. Geophys., 37, 275-316, https://doi.org/10.1029/1999RG900008, 1999.

Sotelo, J. L., Beltrán, F. J., Benitez, F. J., and BeltránHeredia, J.: Henry's Law Constant For The Ozone-Water System, Water Res., 23, 1239-1246, https://doi.org/10.1016/00431354(89)90186-3, 1989.

Tang, G., Zhu, X., Xin, J., Hu, B., Song, T., Sun, Y., Zhang, J., Wang, L., Cheng, M., Chao, N., Kong, L., Li, X., and Wang, Y.: Modelling study of boundary-layer ozone over northern China - Part I: Ozone budget in summer, Atmos. Res., 187, 128-137, https://doi.org/10.1016/j.atmosres.2016.10.017, 2017.

Toumi, R., Bekki, S., and Law, K. S.: Indirect influence of ozone depletion on climate forcing by clouds, Nature, 372, 348-351, 1994.

Trostl, J., Chuang, W. K., Gordon, H., Heinritzi, M., Yan, C., Molteni, U., Ahlm, L., Frege, C., Bianchi, F., Wagner, R., Simon, M., Lehtipalo, K., Williamson, C., Craven, J. S., Duplissy, J., Adamov, A., Almeida, J., Bernhammer, A. K., Breitenlechner, M., Brilke, S., Dias, A., Ehrhart, S., Flagan, R. C., Franchin, A., Fuchs, C., Guida, R., Gysel, M., Hansel, A., Hoyle, C. R., Jokinen, T., Junninen, H., Kangasluoma, J., Keskinen, H., Kim, J., Krapf, M., Kurten, A., Laaksonen, A., Lawler, M., Leiminger, M., Mathot, S., Mohler, O., Nieminen, T., Onnela, A., Petaja, T., Piel, F. M., Miettinen, P., Rissanen, M. P., Rondo, L., Sarnela, N., Schobesberger, S., Sengupta, K., Sipila, M., Smith, J. N., Steiner, G., Tome, A., Virtanen, A., Wagner, A. C., Weingartner, E., Wimmer, D., Winkler, P. M., Ye, P., Carslaw, K. S., Curtius, J., Dommen, J., Kirkby, J., Kulmala, M., Riipinen, I., Worsnop, D. R., Donahue, N. M., and Baltensperger, U.: The role of low-volatility organic compounds in initial particle growth in the atmosphere, Nature, 533, 527-531, https://doi.org/10.1038/nature18271, 2016.

Turner, M. C., Jerrett, M., Pope III, C. A., Krewski, D., Gapstur, S. M., Diver, W. R., Beckerman, B. S., Marshall, J. D., Su, J., Crouse, D. L., and Burnett, R. T.: Long-Term Ozone Exposure and Mortality in a Large Prospective Study, Am. J. Resp. Crit. Care, 193, 1134-1142, https://doi.org/10.1164/rccm.2015081633OC, 2016. 
US National Research Council: Rethinking the ozone problem in urban and regional air pollution, The National Academies Press, Washington, DC, https://doi.org/10.17226/1889, 1991.

Vingarzan, R.: A review of surface ozone background levels and trends, Atmos. Environ., 38, 3431-3442, https://doi.org/10.1016/j.atmosenv.2004.03.030, 2004.

Wang, T., Xue, L., Brimblecombe, P., Lam, Y. F., Li, L., and Zhang, L.: Ozone pollution in China: A review of concentrations, meteorological influences, chemical precursors, and effects, Sci. Total Environ., 575, 1582-1596, https://doi.org/10.1016/j.scitotenv.2016.10.081, 2017.
Zhou, P., Ganzeveld, L., Rannik, Ü., Zhou, L., Gierens, R., Taipale, D., Mammarella, I., and Boy, M.: Simulating ozone dry deposition at a boreal forest with a multi-layer canopy deposition model, Atmos. Chem. Phys., 17, 1361-1379, https://doi.org/10.5194/acp-17-1361-2017, 2017. 